whether "endogenous" or "reactive" need not concern us here-and that the disappearance of the compulsion is a direct consequence of the improvement in mood. We would need to examine a group of compulsive eaters who remained depressed after jejeunoileostomy to test this hypothesis and so far we have not found such a combination of features. Certainly, this explanation would be consistent with the conclusion that depression accompanying obesity is often consequential rather than causal.

We thank Professor W. H. Trethowan for his helpful advice and Dr. Ellis Bindman for providing further information about case 6 .

\section{References}

Baddeley, R. M. (1973). Proceedings of the Royal Society of Medicine, 139, 1098.

British Medical fournal. (1974). 2, 575.

Eysenck, H. J., and Wilson, G. D. (1974). Experimental Study of Freudian Theories. London, Methuen.

Glucksman, M. L. (1972). Advances in Psychosomatic Medicine, 7, 194. Green, R., and Rau, J. (1974). American fournal of Psychiatry, 131, 4, 428. Harris, J., and Frame, B. (1968). Cited by Solow et al 1974.

Levitz, L. S., and Stunkard, A. J. (1974). American fournal of Psychiatry, $131,4,423$.

Payne, J. H., et al. (1973). Archives of Surgery, 106, 432.

Rachman, S. (1971). Effects of Psychotherapy. Oxford, Pergamon.

Solow, C., Silberfarb, P., and Swift, K. (1974). New England fournal of Medicine, 290, 300.

Wittkower, E. D. (1971). Psychosomatics, 12, 21.

\title{
Total Body Potassium in Long-Term Frusemide Therapy: Is Potassium Supplementation Necessary?
}

\author{
H. J. DARGIE, K. BODDY, \\ A. C. KENNEDY, \\ PRISCILLA C. KING, \\ P. R. READ, \\ D. M. WARD
}

British Medical fournal, 1974, 4, 316-319

\section{Summary}

Measurements of total body potassium (T.B.K.) were made by whole-body counting in four groups of patients receiving oral frusemide for one year. Patients in group 1 had essential hypertension and normal renal function and received $40 \mathrm{mg}$ frusemide daily without potassium supplements. Patients in group 2 were similar but received oral potassium supplements for the first four months of treatment. Patients in group 3 had hypertension associated with renal disease and received $120 \mathrm{mg}$ frusemide daily without potassium supplements. Patients in group 4 also had hypertension and renal impairment and in addition to $120 \mathrm{mg}$ frusemide daily they received oral potassium supplements for four months. No evidence of depletion of T.B.K. was found in any of the groups after continuous treatment with frusemide for one year. It is questioned whether potassium supplementation in long term diuretic therapy with frusemide is necessary unless there is evidence of pre-existing potassium depletion or of some other factor such as cardiac failure, cirrhosis of the liver, or the nephrotic syndrome.

\section{Introduction}

The development of hypokalaemia may complicate long-term diuretic therapy (Talso and Carballo, 1960; Remenchick et al., 1966; George et al., 1973), but since the total extracellular fluid space contains only $3 \%$ of the total body content of potassium plasma potassium levels may not accurately reflect the total body or intracellular potassium status (Healy et al., 1970; White,

University Department of Medicine, Royal Infirmary, Glasgow H. J. DARGIE, M.B., M.R.C.P., Medical Registrar (Present address: Royal Postgraduate Medical School, London)

A. C. KENNEDY, M.D., F.R.C.P., Professor of Medicine

P. R. READ, M.B., Clinical Research Assistant

Scottish Research Reactor Centre, East Kilbride

K. BODDY, B.SC., PH.D., Physicist

PRISCILLA C. KING, B.SC., PH.D., Physicist
1970; Flear, 1972; Graybiel and Sode, 1971). We therefore used the only direct method of estimating total body potassium (T.B.K.), whole-body counting, to assess the influence of longterm treatment with frusemide in patients with normal and diminished renal function. As potassium supplements are given customarily with diuretics, often without reference to the status of T.B.K., their effectiveness was also examined.

\section{Patients and Methods}

Twenty-nine patients, with their consent, were included in the study and were divided into four groups according to renal function and whether or not they were receiving potassium supplements. The clinical details are summarized in table I. Patients in group 1 had essential hypertension and normal renal function and were treated with frusemide $40 \mathrm{mg}$ daily for one year without potassium supplements. Patients in group 2 were similar but in addition to frusemide $40 \mathrm{mg}$ daily they received effervescent potassium chloride $24 \mathrm{mEq}$ daily for the first four months of treatment. Thereafter they continued on frusemide alone. Patients in group 3 had hypertension associated with renal disease, the range of endogenous creatinine clearance being $11-60 \mathrm{ml} / \mathrm{min}$ with a mean of $22 \mathrm{ml} / \mathrm{min}$. They received frusemide $120 \mathrm{mg}$ daily for one year without potassium supplements. Patients in group 4 also had renal impairment but had a higher mean rate of endogenous creatinine clearance $(43 \mathrm{ml} / \mathrm{min})$ and as well as frusemide $120 \mathrm{mg}$ daily they received effervescent potassium chloride $24 \mathrm{mEq}$ daily for the first four months and then continued on frusemide alone for a further eight months. None of the patients had cardiac failure or oedema of other origin and none had received a diuretic in the past two years. Other antihypertensive therapy was continued as before. No patients were receiving $\beta$-blocker drugs and the distribution of antihypertensive therapy was not dissimilar in the groups.

At the beginning of the study baseline measurements were made of T.B.K. and the plasma concentration of potassium, urea, creatinine, uric acid, blood sugar, chloride, and $\mathrm{CO}_{2}$. Blood pressure was also recorded using a standard cuff sphygmomanometer. The Merlin mobile whole-body counter (Boddy, 1967) was used to estimate T.B.K. by measuring the $1 \cdot 46-\mathrm{Mev}$ gamma-rays of the naturally occurring endogenous ${ }^{4} \mathrm{~K}$, which is a constant fraction of T.B.K. The calibration procedure described previously (Boddy et al., 1971) was applied. The coefficient of variation has been shown (Boddy et al., 1971) to be $2 \cdot 7 \%$ for the $70 \mathrm{~kg}$ man with $140 \mathrm{~g}$ potassium. The patients 
TABLE I-Clinical Details of Patients in each Group

\begin{tabular}{|c|c|c|c|c|c|c|}
\hline \multirow{2}{*}{ Group } & \multirow{2}{*}{ No. of Patients } & \multirow{2}{*}{ Mean Age (Range) } & \multicolumn{2}{|c|}{ Sex } & \multirow{2}{*}{$\begin{array}{c}\text { Mean (Range) } \\
\text { Creatinine Clearance } \\
(\mathrm{ml} / \mathrm{min})\end{array}$} & \multirow{2}{*}{ Diagnosis } \\
\hline & & & M. & F. & & \\
\hline $\begin{array}{l}1 \\
2 \\
3\end{array}$ & $\begin{array}{l}8 \\
6 \\
9\end{array}$ & $\begin{array}{l}44(27-69) \\
48(44-59) \\
42(15-56)\end{array}$ & $\begin{array}{l}2 \\
4 \\
2\end{array}$ & $\begin{array}{l}6 \\
2 \\
7\end{array}$ & $\begin{array}{l}84(70-100) \\
95(70-130) \\
22(11-60)\end{array}$ & $\begin{array}{l}\text { Essential hypertension } \\
\text { Essential hypertension } \\
\text { Chronic pyelonephritis 6, }\end{array}$ \\
\hline 4 & 6 & $41(30-55)$ & 3 & 3 & $43(20-63)$ & $\begin{array}{l}\text { Chronic pyelonephritis } 3 \text {, } \\
\text { chronic glomerulonephritis } 2 \text {, } \\
\text { polycystic kidneys } 1\end{array}$ \\
\hline
\end{tabular}

were seen routinely at monthly intervals and the above series of measurements were repeated four months and 12 months after starting treatment.

The measured T.B.K. in each patient was compared with estimated normal values derived from regression equations (Boddy et al., 1972) using the height and age and also the height, weight, and age of the patient.

The results were analysed statistically using a paired Student's $t$ test on the individual's results obtained before and after the treatment periods.

\section{Results}

The total body potassium (T.B.K.) data for each patient is given in fig. 1 and the mean values for each group in table II. A slight though significant reduction in T.B.K. occurred at four months in group 1. This was followed, however, by a small but statistically significant rise between four and 12 months such that the values at 12 months did not differ significantly from those obtained before treatment. No significant reductions occurred in any of the other groups at either four or 12 months. In the two groups (groups 2 and 4 ) receiving potassium supplements there was no significant difference in T.B.K. throughout the study.

Though there was a significant reduction in T.B.K. in group 1 between the start of treatment and four months later comparison of the T.B.K. values measured with the normal values predicted from the individual's height, weight, and age and height and age showed no evidence of potassium depletion in

TABLE II-Mean Values ( \pm S.E.) of Total Body Potassium before and after Four and after 12 Months

\begin{tabular}{c|c|c|c}
\hline \multirow{2}{*}{ Group } & \multicolumn{3}{|c}{ Total Body Potassium $(\mathrm{g})$} \\
\cline { 2 - 4 } & \multicolumn{1}{|c|}{ Baseline } & \multicolumn{1}{|c}{ 4 Months } & \multicolumn{1}{c}{12 Months } \\
\hline 1 & $110.9 \pm 10 \cdot 1$ & $102.6 \pm 7.5$ & $107 \cdot 2 \pm 8 \cdot 1$ \\
2 & $116.6 \pm 11.4$ & $115.8 \pm 10 \cdot 2$ & $114.8 \pm 10 \cdot 7$ \\
3 & $92.9 \pm 6.4$ & $91.8 \pm 5.9$ & $97.8 \pm 5.3$ \\
4 & $108.9 \pm 8.8$ & $106.3 \pm 9 \cdot 1$ & $105.2 \pm 8.5$ \\
\hline
\end{tabular}

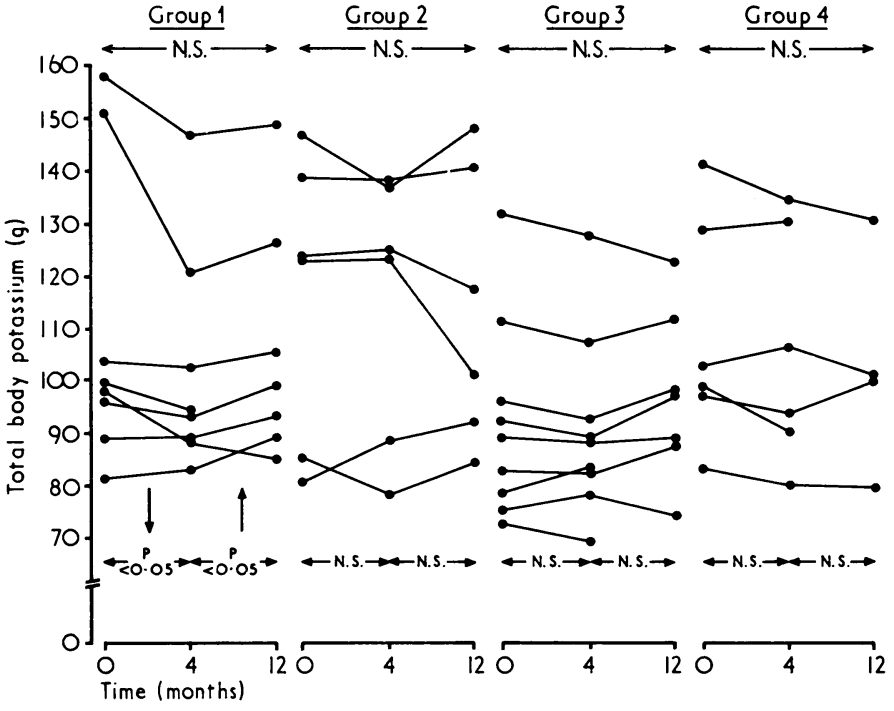

FIG. 1-Values of total body potassium at 0,4 , and 12 months in four groups of patients studied.

this group of patients at the four-month stage nor in any of the other groups either at four of 12 months.

The corresponding mean plasma potassium values (plasma $\mathrm{K}$ ) are summarized in table III. A slight but significant reduction occurred in group 1 at four months and though there was no further reduction over the ensuing eight months the values at 12 months were significantly lower than those before treatment. No significant reduction occurred in group 2 at four months but between four and 12 months a slight but significant reduction occurred. The values at 12 months, however, were not significantly different from those at the start of treatment. In group 3 there was a small but significant reduction at four months but this was not progressive and the values at 12 months did not differ significantly from pretreatment values. No reduction occurred in group 4 at either four or 12 months. Though significant reductions occurred in some groups, in no group did the mean

TABLE III-Mean Values ( \pm S.E.) Plasma K, Plasma Chloride, and Plasma $\mathrm{CO}_{2}$ Content before and after Four and after 12 Months

\begin{tabular}{|c|c|c|c|c|c|c|}
\hline \multirow{2}{*}{ Group } & \multirow{2}{*}{ Baseline } & \multirow{2}{*}{4 Months } & \multirow{2}{*}{12 Months } & \multicolumn{3}{|c|}{$\mathbf{P}$} \\
\hline & & & & 0-4 Months & 4-12 Months & $0-12$ Months \\
\hline \multicolumn{7}{|c|}{ PlasmaK $(m E q / l)}$. \\
\hline $\begin{array}{l}1 \\
2 \\
3 \\
4\end{array}$ & $\begin{array}{l}3.9 \pm 0.1 \\
3 \cdot 9 \pm 0 \cdot 1 \\
4 \cdot 5 \pm 0 \cdot 2 \\
4 \cdot 2 \pm 0.2\end{array}$ & $\begin{array}{l}3 \cdot 6 \pm 0 \cdot 1 \\
4 \cdot 0 \pm 0 \cdot 2 \\
4 \cdot 0 \pm 0 \cdot 1 \\
4 \cdot 0 \pm 0 \cdot 1\end{array}$ & $\begin{array}{l}3.6 \pm 0.1 \\
3.7 \pm 0.2 \\
4.2 \pm 0.3 \\
3.8 \pm 0.2\end{array}$ & $\begin{array}{l}<0.05 \\
\text { N.S. } \\
<0.01 \\
\text { N.S. }\end{array}$ & $\begin{array}{l}\text { N.S. } \\
<0.05 \\
\text { N.S. } \\
\text { N.S. }\end{array}$ & $\begin{array}{l}<0.05 \\
\text { N.S. } \\
\text { N.S. } \\
\text { N.S. }\end{array}$ \\
\hline \multicolumn{7}{|c|}{ Plasma Chloride (mEq/l.) } \\
\hline $\begin{array}{l}1 \\
2 \\
3 \\
4\end{array}$ & $\begin{array}{l}103.3 \pm 1.0 \\
103.4 \pm 0.9 \\
107.6 \pm 1.3 \\
106.7 \pm 1.7\end{array}$ & $\begin{array}{r}100.9 \pm 1.0 \\
98.6 \pm 0.7 \\
103.5 \pm 1.3 \\
101.2 \pm 1.7\end{array}$ & $\begin{array}{c}102 \pm 1.0 \\
99.1 \pm 1.0 \\
104.4 \pm 0.8 \\
103.0 \pm 0.9\end{array}$ & $\begin{array}{l}<0.01 \\
<0.01 \\
<0.01 \\
<0.005\end{array}$ & $\begin{array}{l}\text { N.S. } \\
\text { N.S. } \\
\text { N.S. } \\
\text { N.S. }\end{array}$ & $\begin{array}{l}\text { N.S. } \\
<0.01 \\
<0.025 \\
\text { N.S. }\end{array}$ \\
\hline \multicolumn{7}{|c|}{ Plasma $\mathrm{CO}_{2}$ Content $(\mathrm{mmol} / \mathrm{l}$.) } \\
\hline $\begin{array}{l}1 \\
2 \\
3 \\
4\end{array}$ & $\begin{array}{l}25 \cdot 5 \pm 0 \cdot 5 \\
27 \cdot 0 \pm 0 \cdot 6 \\
18 \cdot 6 \pm 1 \cdot 3 \\
22 \cdot 5 \pm 1 \cdot 3\end{array}$ & $\begin{array}{l}27 \cdot 4 \pm 1 \cdot 3 \\
27 \cdot 0 \pm 0 \cdot 8 \\
20 \cdot 7 \pm 1 \cdot 2 \\
23 \cdot 6 \pm 1 \cdot 7\end{array}$ & $\begin{array}{l}26 \cdot 5 \pm 1.0 \\
25 \cdot 6 \pm 0.5 \\
20.9 \pm 1 \cdot 1 \\
23.6 \pm 0.5\end{array}$ & $\begin{array}{l}\text { N.S. } \\
\text { N.S. } \\
\text { <0.025 } \\
\text { N.S. }\end{array}$ & $\begin{array}{l}\text { N.S. } \\
\text { N.S. } \\
\text { N.S. } \\
\text { N.S. }\end{array}$ & $\begin{array}{l}\text { N.S. } \\
\text { N.S. } \\
<0.025 \\
\text { N.S. }\end{array}$ \\
\hline
\end{tabular}


plasma potassium values fall below the lower limit of the normal range for our laboratory $(3.5 \mathrm{mEq} / 1$.). The six lowest individual plasma $\mathrm{K}$ values $(3 \cdot 0-3 \cdot 5 \mathrm{mEq} / \mathrm{l}$.) are given in table IV together with the ratio for each patient of the measured to estimated normal T.B.K. It can be seen that none of the plasma values were frankly hypokalaemic and that the plasma values were poor indicators of T.B.K. status. None of these patients complained of symptoms attributable to hypokalaemia nor were there any changes in the electrocardiographic appearances. A typical case is illustrated in fig. 2 in which rather low plasma $K$ values occurred despite measured T.B.K. values which were not significantly different from expected values.

TABLE IV-Lack of Correlation between Low PlasmaK Values in Six Patients and Ratio of Measured $(m)$ to Estimated (e) Total Body Potassium (T.B.K.)

\begin{tabular}{|c|c|c|c|c|c|c|}
\hline $\begin{array}{l}\text { Plasma K (mEq/l.) } \\
\text { T.B.K.m:T.B.K.e }\end{array}$ & $\begin{array}{l}3.2 \\
0.89\end{array}$ & $\begin{array}{l}3.4 \\
1.01\end{array}$ & $\begin{array}{l}3 \cdot 4 \\
1 \cdot 0\end{array}$ & $\begin{array}{l}3.4 \\
1.08\end{array}$ & $\begin{array}{l}3 \cdot 3 \\
1 \cdot 2\end{array}$ & $\begin{array}{l}3 \cdot 2 \\
0.92\end{array}$ \\
\hline
\end{tabular}

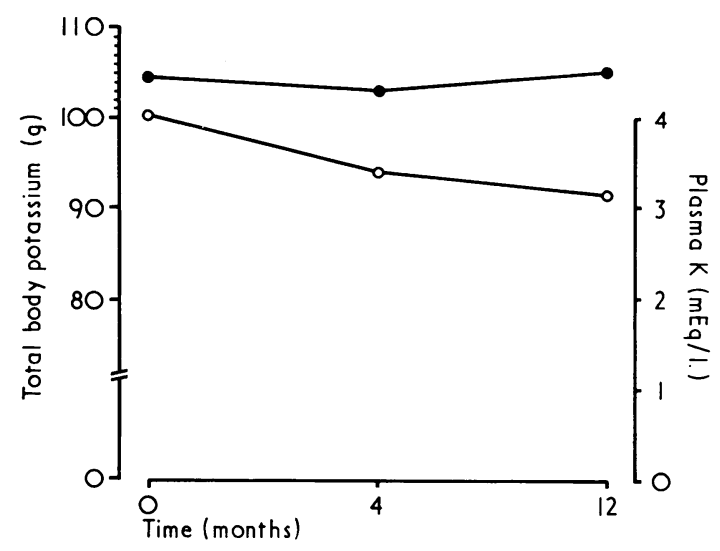

FIG. 2-Normal total body potassium values at 0,4 , and 12 months in one patient from group 1 despite fall in plasma $\mathrm{K}$ value. $\mathrm{O}=$ Plasma $\mathrm{K}$. $=$ Total body potassium.

Significant reductions in mean chloride values occurred in all groups at four months but there was no further decrease at 12 months (table III). In fact comparison of the pretreatment mean chloride values with the 12 -month values showed a significant reduction only in groups 2 and 3. No significant changes occurred in $\mathrm{CO}_{2}$ levels in groups 1,2 , and 4 . In group 3 a slight increase in mean $\mathrm{CO}_{2}$ values was evident at four and 12 months.

Plasma urea, creatinine, and uric acid values before treatment and after 12 months are summarized in table V. Plasma urea rose in all groups and significantly in groups 1 and 3 , the mean increases being $5.3 \mathrm{mg} / 100 \mathrm{ml}$ and $9.0 \mathrm{mg} / 100 \mathrm{ml}$ respectively. Plasma creatinine rose slightly in all groups, this being significant, however, only in group 4 where there was a mean increase of $0.5 \mathrm{mg} / 100 \mathrm{ml}$. Plasma uric acid rose significantly in all groups though at no time did any patient develop symptoms suggestive of gout. Hyperglycaemia or glycosuria were not detected in any patient at any time.
There was a fall in the mean value of standing diastolic blood pressure of $5.8 \mathrm{~mm} \mathrm{Hg}$ and $5.7 \mathrm{~mm} \mathrm{Hg}$ in groups 1 and 2 respectively. The fall in mean value of blood pressure was more marked in the patients with diminished renal function (who received a higher dose of frusemide), decreases of $13.1 \mathrm{~mm} \mathrm{Hg}$ and $12.3 \mathrm{~mm} \mathrm{Hg}$ in standing diastolic pressure being recorded for groups 3 and 4 respectively. These results were significant at the $5 \%$ level but as previously indicated the readings were not taken under control conditions.

\section{Discussion}

No evidence of depletion of T.B.K. was found in any of the groups of patients in this study after continuous treatment with frusemide for one year. No other study of T.B.K. in patients treated with frusemide for a similar length of time has been reported, but in a shorter study Anderson et al. (1971) found no significant change in T.B.K. in hypertensive patients treated with frusemide $40 \mathrm{mg}$ twice daily for 8 weeks. Healy et al. (1970) reported moderate reductions in total exchangeable potassium (T.E.K.) in hypertensive patients after 15 weeks treatment with frusemide $40 \mathrm{mg}$ twice daily and it is interesting that the mean reduction in T.E.K. found $(247 \mathrm{mEq}$, which is equivalent to $9.8 \mathrm{~g}$ potassium) is comparable to the reduction in mean T.B.K. seen in our group 1 at 16 weeks. The return to pretreatment values of T.B.K. in group 1 after 12 months of therapy was also interesting. These patients seemed to be in slight negative potassium balance during the early period of treatment, presumably due to increased urinary potassium losses. As treatment continued there may have been a lessening of urinary potassium losses despite the continuation of other effects of frusemide such as the hypotensive effect and the raised plasma uric acid levels. This phenomenon has been reported before with T.E.K. levels in hypertensive patients treated with thiazide diuretics (Talso and Carballo, 1960; Gifford et al., 1961), and Talso and Carballo (1960) showed a reduction in urinary potassium excretion with prolonged therapy. This is analogous to the effect of diuretic therapy on exchangeable sodium levels since an initial reduction followed by a return to normal values has been well documented (Talso and Carballo, 1960; Bartorelli et al., 1966; Lauwers and Conway, 1960). An alternative but unproven explanation is that there may have been a compensatory rise in intestinal $\mathrm{K}$ absorption.

Though there were statistically significant reductions in plasma $K$ values in groups 1 and 3 (who did not receive $K$ supplements) it should be emphasized that the degree of reduction was about $0 \cdot 3-0.5 \mathrm{mEq} / \mathrm{l}$. and that the mean plasma $\mathrm{K}$ values in all groups remained in the normal range. Similar small reductions have been noted by other workers (Healy et al., 1970; Anderson et al., 1971). The slight reduction in plasma potassium may have been the result of the transient reduction in T.B.K. but a further possible mechanism may have been a redistribution of extracellular fluid potassium, there being a slight shift into the cells consequent upon the mild hypochloraemic alkalosis produced by the diuretic (Talso and Carballo, 1960; Flear, 1972). In the present study mean plasma chloride levels were lower in all groups at four months but only in groups 2 and 3 was the reduction significant at 12 months. Though a statistically significant rise in plasma $\mathrm{CO}_{2}$ content occurred only in group 3

TABLE V-Mean Values ( \pm S.E.) of Plasma Urea, Creatinine, and Uric Acid before and after 12 Months

\begin{tabular}{|c|c|c|c|c|c|c|c|c|c|}
\hline \multirow{2}{*}{ Group } & \multicolumn{2}{|c|}{ Urea (mg/100 ml) } & \multirow[b]{2}{*}{$\mathbf{P}$} & \multicolumn{2}{|c|}{ Creatinine $(\mathrm{mg} / 100 \mathrm{ml})$} & \multirow[b]{2}{*}{$\mathbf{P}$} & \multicolumn{2}{|c|}{ Uric acid $(\mathrm{mg} / 100 \mathrm{ml})$} & \multirow[b]{2}{*}{$\mathbf{P}$} \\
\hline & Baseline & 12 Months & & Baseline & 12 Months & & Baseline & 12 Months & \\
\hline $\begin{array}{l}1 \\
2 \\
3 \\
4\end{array}$ & $\begin{array}{l}31 \cdot 2 \pm 2 \cdot 7 \\
33 \cdot 1 \pm 3 \cdot 2 \\
83 \cdot 8 \pm 9 \cdot 2 \\
52 \cdot 8 \pm 4 \cdot 2\end{array}$ & $\begin{array}{l}36.5 \pm 1.9 \\
40.0 \pm 5.5 \\
92.8 \pm 10 \cdot 2 \\
64.8 \pm 6.3\end{array}$ & $\begin{array}{l}<0.05 \\
\text { N.S. } \\
<0.05 \\
\text { N.S. }\end{array}$ & $\begin{array}{c}0.90 \pm 0.07 \\
1.05 \pm 0.16 \\
3.3 \pm 0.6 \\
2.0 \pm 0.3\end{array}$ & $\begin{array}{l}0.97 \pm 0.07 \\
1.16 \pm 0.08 \\
3.9 \pm 1.0 \\
2.5 \pm 0.5\end{array}$ & $\begin{array}{l}\text { N.S. } \\
\text { N.S. } \\
\text { N.S. } \\
<0.025\end{array}$ & $\begin{array}{r}5 \cdot 1 \pm 0.8 \\
5 \cdot 0 \pm 0.6 \\
7.6 \pm 0.8 \\
7.1 \pm 0.9\end{array}$ & $\begin{array}{l}6 \cdot 4 \pm 0 \cdot 5 \\
7 \cdot 0 \pm 0 \cdot 7 \\
8 \cdot 8 \pm 1 \cdot 1 \\
8 \cdot 7 \pm 1 \cdot 0\end{array}$ & $\begin{array}{r}<0.0005 \\
<0.0025 \\
<0.025 \\
<0.025\end{array}$ \\
\hline
\end{tabular}


there were some individual patients in other groups who showed small rises and the overall evidence may therefore be in favour of a redistribution phenomenon to account for the small reductions in plasma potassium level noted. The poor correlation between the slightly low plasma potassium levels in some patients and the ratio between the measured T.B.K. and expected T.B.K. confirms the view of many investigators (Healy et al., 1970; White, 1970; Flear, 1970; Graybiel and Sode, 1971) that the plasma potassium level is a relatively poor guide to the whole body potassium status. Edmonds and Jasani (1972), however, reported a good correlation between plasma potassium levels and the ratio between measured T.B.K. (T.B.K.m) and expected T.B.K. (T.B.K.e) when all the patients studied were included in the analysis. The reason for this may be that most plasma potassium levels and T.B.K.m: T.B.K.e ratios were within the normal range, but it should be noted that several of the most depleted patients, many of whom had cardiac complications, had plasma potassium levels within the normal range.

The results of this study clearly question the necessity for potassium supplementation in long term diuretic therapy with frusemide unless, of course, there is evidence of pre-existing potassium depletion or of some other factor such as cardiac failure, cirrhosis of the liver, or the nephrotic syndrome. It is irksome for patients to take three to eight potassium tablets a day, particularly if several other drugs, such as antihypertensive agents, are also being taken. Since it has been calculated (George et al., 1973) that $70 \%$ of patients attending one blood pressure clinic are on diuretic therapy the issue is potentially a large one with obvious economic implications. The evidence from this study is that when frusemide is given as an adjunct to antihypertensive therapy in non-oedematous patients who are not potassium depleted routine potassium supplements are not required. Also, when potassium supplements are given to patients with normal renal function who are not potassium depleted these are not retained (Bartorelli et al., 1966; Down et al., 1972), which is in contrast to the situation in potassiumdepleted patients in whom retention of potassium supplements has been shown (McKenna et al., 1971).

Thiazides are perhaps more commonly prescribed as an adjunct to antihypertensive therapy in patients with normal renal function. We have not measured T.B.K. in such patients but in two studies (Anderson et al., 1971; Graybiel and Sode, 1971) no significant reduction in T.B.K. was evident after two and 12 months respectively. Some studies have shown significant reductions in T.E.K. (Healy et al., 1970; Bartorelli et al., 1966; Winer, 1961) but the following comments may be made. In the study of Bartorelli et al. (1966) the dietary intake of potassium, estimated at only $30-40 \mathrm{mEq} /$ day, was inadequate and the study lasted only 48 days. In another short-term study lasting four weeks (Winer, 1961) significant reductions in T.E.K. were found in some patients, but the dose of hydrochlorothiazide $(150 \mathrm{mg}$ ) was higher than is often prescribed as an adjunct to antihypertensive therapy. The study of Healy et al. (1970) was longer (10-15 weeks), but though significant reductions in T.E.K. occurred the authors concluded that in the absence of any symptoms attributable to hypokalaemia these reductions were acceptable.
Hyperkalaemia, which is a potentially more dangerous condition than the mild hypokalaemia often associated with diuretic therapy, did not occur in any of the patients in this study who had renal impairment and who were given potassium supplements. Nevertheless, hyperkalaemia remains a potential hazard in such patients and it may not be coincidental that more deaths have been reported from this cause in patients treated with diuretics and potassium supplements than have been attributed to hypokalaemia (Lawson, 1974).

The situation is different in oedematous conditions such as cardiac failure and cirrhosis of the liver. In cardiac failure (White, 1970; Flear, 1972; Edmondson et al., 1974) it has been shown that potassium depletion may be present possibly as a consequence of inability of the cell to accumulate potassium because of tissue anoxia, together with promotion of urinary potassium excretion due to secondary hyperaldosteronism (Flear, 1972).

Materson et al. (1970) have shown that potassium supplements or potassium sparing diuretics or both are indicated in patients with cirrhosis of the liver. Apart from this study we have made limited observations of T.B.K. in patients treated with much higher doses of frusemide (500-1000 mg). While marked reductions in T.B.K. were noted in two patients with cardiac failure in association with renal impairment no significant reductions occurred in three patients with the nephrotic syndrome who had normal or only slightly impaired renal function. This is in agreement with the hypothesis that, with respect to cardiac failure, potassium depletion may result from tissue anoxia rather than from the treatment given (Edmondson et al., 1974). Though the role of potassium supplements in the nephrotic syndrome remains to be defined, in the specific circumstances of cardiac failure and cirrhosis of the liver it is widely accepted that potassium supplements should be given along with diuretic therapy.

\section{References}

Anderson, J., et al. (1971). Quarterly fournal of Medicine, 40, 541.

Bartorelli, C., Gargano, N., and Leonetti, G. (1966). In Antihypertensive Therapy, ed. F. Gross, p. 422. Berlin, Springer.

Boddy, K. (1967). British fournal of Radiology, 40, 631.

Boddy, K., et al. (1972). Fournal of Clinical Pathology, 25, 512.

Boddy, K., et al. (1971). Physics in Medicine and Biology, 16, 275.

Down, P. F., et al. (1972). Lancet, 2, 721.

Edmonds, C. J., and Jasani, B. (1972). Lancet, $2,8$.

Edmonds, C. J., and Jasani, B. (1972). Lancet, 2, 8.

Flear, C. T. G. (1972). Adverse Drug Reaction Bulletin, No. 32, p. 96.

Gear, C. T. G. (1972). Adverse Drug Reaction Bulletin, No. 32, p. 96. 1288 .

Gifford, R. W., et al. (1961). Circulation, 24, 1197.

Graybiel, A. L., and Sode, J. (1971). Lancet, 2, 265.

Healy, J. J., et al. (1970). British Medical fournal, 1, 716.

Lauwers, P., and Conway, J. (1960). Fournal of Laboratory and Clinical Medicine, 56, 401.

Lawson, D. (1974). Quarterly Fournal of Medicine. In press.

McKenna, T. J., et al. (1971). British Medical fournal, 2, 739. Research, 18, 38.

Remenchick, A. P., et al. (1966). Circulation, 33, 796.

Talso, P. J., and Carballo, A. J. (1960). Annals of the New York Academy of Sciences, 88, 822.

White, R. J. (1970). British Medical fournal, 3, 141.

Winer, B. M. (1961). Circulation, 23, 211. 